\title{
Morphometry of the mandibular foramen applied to local anesthesia in hoary fox (Lycalopex vetulus) ${ }^{1}$
}

\author{
Henrique I.R. Magalhães ${ }^{2 *}$ (D), Fabiano B. Romão², Ygor Henrique de Paula², \\ Marcos M. Luz ${ }^{2}$, Jeferson B. Barcelos ${ }^{3}$, Zenon Silva ${ }^{4}$, Roseâmely A. Carvalho-Barros ${ }^{4}$ \\ and Lucas A. Ribeiro ${ }^{2}$
}

\begin{abstract}
Magalhães H.I.R., Romão F.B., Paula Y.H., Luz M.M., Barcelos J.B., Silva Z., Carvalho-Barros R.A. \& Ribeiro L.A. 2019. Morphometry of the mandibular foramen applied to local anesthesia in hoary fox (Lycalopex vetulus). Pesquisa Veterinária Brasileira 39(4):278-285. Laboratório de Anatomia Animal, Faculdade de Medicina Veterinária, Centro Universitário de Patos de Minas, Rua Major Gote 808, Caiçaras, Patos de Minas, MG 38702-054, Brazil. E-mail: henrique123magalhaes@yahoo.com.br

Great part of the veterinary care in wild carnivores is intended to treat the dental disorders, and oral cavity disorders may generally affect the animal health as a whole. It is factual that knowing the location of the mandibular foramen is vital for local anesthetic block of the inferior alveolar nerve, however, there is still no data on the morphometry of the hoary fox mandibular foramen. The aim was describing morphometry of the mandibular foramen of this species and associating its position with anatomic reference points in the mandible, thus providing support for more effective local anesthetic block of the inferior alveolar nerve in such species. Four adult jaws of Lycalopex vetulus were used. Radiography and biometrics of the hemimandibulas were performed. The rostral third of the jaw body in a lateral view presented three mental foramens, being a rostral, a medium and a caudal. Each hemimandibula presented I3/C1/PM4/M3. The angle of the mandible was marked by the masseteric fossa, the angular incisure, the angular process and the mandibular foramen, and this last one located perpendicularly to the dorsal edge of the angular incisures in medial view. In this view, the crevice to the milohyoid nerve, projected in the caudodorso rostral direction, was also evidenced. The ramus of the mandible was characterized by the presence of the condylar and coronoid processes, and by the dorsal and ventral mandibular incisions. Statistical analyzes did not present significant differences between the antimeres of the studied animals, and the penetration of the needle perpendicularly to the dorsal end of the angular incision on average $8.79 \mathrm{~mm}$, overlapped to the medial face of the angle of the mandible could be indicated. Alternatively, the access may also be achieved by inserting the needle in an average of $17.69 \mathrm{~mm}$ perpendicular to the dorsal end of the angular process, in contact with the medial aspect of the angle of the mandible, and in caudo-rostral projection, also allowing a better anesthetic blockade of the inferior alveolar nerve in L. vetulus. It can also be concluded that the masseteric fossa, the dorsal and ventral mandibular angles, the crevice to the milohyoid nerve, the ramus of the mandible and the mandibular foramen presented differences in their topographic descriptions when compared to the other canids.
\end{abstract}

INDEX TERMS: Morphometry, anesthesia, mandibular foramen, hoary fox, Lycalopex vetulus, jaw, morphology.

\footnotetext{
${ }^{1}$ Received on October 4, 2018.

Accepted for publication on November 5, 2018.

${ }^{2}$ Laboratório de Anatomia Animal, Faculdade de Medicina Veterinária, Centro Universitário de Patos de Minas (Unipam), Rua Major Gote 808, Caiçaras,PatosdeMinas,MG 38702-054.Brazil.E-mails:fabianobrazromao@gmail.com,ygor.henrique97@gmail.com, marcosveterinaria@yahoo.com.br, lucasassis83@yahoo.com.br; *Corresponding author: henrique123magalhaes@yahoo.com.br
}

\footnotetext{
${ }^{3}$ Student of Veterinary Medicine, Fundação Presidente Antônio Carlos (Unipac), Praça Clarimundo Carneiro 256, Fundinho, Uberlândia, MG 38400-154, Brazil. E-mail: jefersonbbarcelos@hotmail.com

${ }^{4}$ Laboratório de Anatomia, Faculdade de Ciências Biológicas, Universidade Federal de Goiás (UFG), Campus Catalão, Avenida Dr. Lamartine Pinto de Avelar 1120, Setor Universitário, Catalão, G0 75702-020, Brazil. E-mails: zenon_silva@ufg.br, roseamely@ig.com.br
} 
RESUMO.- [Morfometria do forame mandibular aplicada à anestesia local em raposa-do-campo (Lycalopex vetulus).] A maior parte dos atendimentos veterinários em carnívoros silvestres destina-se ao tratamento das afecções dentárias, sendo que doenças de cavidade oral podem afetar a saúde do animal como um todo. É factível que o conhecimento da localização do forame mandibular é essencial para o bloqueio anestésico local do nervo alveolar inferior, entretanto, ainda são inexistentes dados sobre a morfometria do forame mandibular de raposa-do-campo. Objetivou-se descrever a morfometria do forame mandibular desta espécie, e correlacionar sua posição com pontos de referência anatômica na mandíbula, oferecendo subsídio para um bloqueio anestésico local mais efetivo do nervo alveolar inferior nesta espécie. Foram utilizadas quatro mandíbulas de cadáveres adultos de Lycalopex vetulus. Realizou-se a radiografia e as biometrias das hemimandíbulas. 0 terço rostral do corpo da mandíbula em uma vista lateral apresentou três forames mentuais, sendo um rostral, um médio e um caudal. Cada hemimandíbula apresentou I3/C1/PM4/M3. O ângulo da mandíbula foi marcado pela fossa massetérica, pela incisura angular, pelo processo angular e pelo forame mandibular, e este último localizado perpendicularmente ao extremo dorsal da incisura angular em vista medial. Nesta vista, também se evidenciou o sulco para o nervo milohióideo, projetado em sentido caudodorsorostral. 0 ramo da mandíbula foi caracterizado pela presença dos processos condilar e coronóide, e pelas incisuras mandibulares dorsal e ventral. As análises estatísticas não apresentaram diferenças significantes entre os antímeros dos animais estudados, podendo-se indicar a penetração da agulha perpendicularmente ao extremo dorsal da incisura angular em média $8,79 \mathrm{~mm}$, justaposto à face medial do ângulo da mandíbula. Alternativamente, o acesso também poderá ser realizado introduzindo a agulha em média $17,69 \mathrm{~mm}$ de forma perpendicular ao extremo dorsal do processo angular, em contato com a face medial do ângulo da mandíbula, e em projeção caudorostral, permitindo também um melhor bloqueio anestésico do nervo alveolar inferior na $L$. vetulus. Também se pode concluir que a fossa massetérica, as incisuras angular, mandibulares dorsal e ventral, o sulco para o nervo milohióideo, o ramo da mandíbula e o forame mandibular apresentaram diferenças em suas descrições topográficas quando comparados aos demais canídeos.

TERMOS DE INDEXAÇÃO: Morfometria, anestesia, forame mandibular, raposa-do-campo, Lycalopex vetulus, mandíbula, morfologia.

\section{INTRODUCTION}

The order Carnivora is comprised of 15 families, 287 species and divided into two suborders: Feliformia and Caniformia (Wozencraft 2005). It is known that approximately 195 species within such suborders inhabit the Brazilian biome Cerrado, out of which 18 are endemic (Brasil 2002). Among the canidae found in such biome, the hoary fox (Lycalopex vetulus Lund, 1842 ) is considered as the smallest among them with its occurrence confirmed only in Brazil (Dalponte \& Courtenay 2004).

The geographic span of this animal species, at first, seems to be associated with the extent thresholds of the Cerrado (Dalponte 2009), but they may also be found in transition zones, including open areas of Pantanal (Lemos et al. 2013). Considering the new information regarding this species occurrence area, we know their living area ranges from Northeastern and Western regions of the State of São Paulo (Dalponte 2009), Northern region in Piauí (Costa \& Courtenay 2003) and middle-eastern region of Maranhão (Lemos et al. 2013).

The Lycalopex vetulus gets to the weight of up to $4.0 \mathrm{~kg}$, and their body ranges from 58.5 to $64.0 \mathrm{~cm}$ and their tail from 28.0 to $32.0 \mathrm{~cm}$ (Nowak 1999). Their head has a red-brownish colored fur and, on the back, their fur has a grey-brownish color, with a dark-colored strip extending from the scruff to the tail edge, being more evident in the adult males (Vieira 1946). Their limbs are whitish, their tail is thick and has a dense fur, which may often have a dark spot in their base (Nowak 1999, Dalponte \& Courtenay 2004).

They have their dental formula by quadrants equivalent to: I 3/3; C 1/1; PM 4/4; M 2/3 = 42 (Cheida et al. 2011), being considered insectivorous-omnivorous carnivores which use as their food basis the termites, also consuming in smaller quantities locusts and beetles. According to their availability in the environment and season of the year, they also feed of wild, exotic fruits, small-sized mammals, lizards and snakes, Anura and birds (Dalponte 1997, Juarez \& Marinho-Filho 2002, Jácomo et al. 2004, Ferreira-Silva \& Lima 2006, Trovati et al. 2006, Dalponte 2009, Lemos et al. 2011).

In the Brazilian States of São Paulo and Minas Gerais, Chiarello et al. (2008) mention the hoary fox as an endangered species (EN), however, this dog is found as a species of Least Concern (LC) as to the endangered scope, under the International Union for Conservation of Nature (IUCN 2017).

Great part of the veterinary care in wild carnivores is intended to treat the dental disorders, and oral cavity disorders may generally affect the animal health as a whole (Pachaly \& Gioso 2001), and cause variable impact upon the wild populations, even suggested as limiting to the life expectancy (Hungerford et al. 1999, Stimmelmayr et al. 2006). For Pachaly \& Gioso (2001), the oral cavity health is directly associated with maintenance of a good nutritional condition, increased reproductive capacity, longevity and life quality of the wild carnivores in captivity.

It is factual that knowing the location of the mandibular foramen is vital for local anesthetic block of the inferior mandibular and alveolar nerves (Nickel et al. 1981, Nicholson 1985 , Blanton \& Roda 1995). The inferior alveolar nerve is a sensitive nerve, derived from the mandibular nerve, which penetrates the mandibular foramen and spreads as it extends along the mandibular canal, in caudal, mean and rostral branches, responsible for both the innervation of the molar teeth, premolar, canine and incisors, and the corresponding gums and the skin of the mental region (Godinho \& Getty 1986).

Local anesthesia provides some benefits, such as decreased central sensitivity to pain, mitigated inflammatory tissue reaction, reduced volume of general anesthetic required during the surgical procedure, and decreased dose and frequency of analgesics used in post-op (Gross et al. 1997, Hellyer \& Gaynor 1998, Holmstrom et al. 2004). For occurrence of the anesthetic stunning of the inferior alveolar nerve, a local anesthetic injection must be administered near the ventral limit of such nerve (Lumb \& Jones 2014).

Thus, knowledge of the topographic anatomy of the mandibular foramen and inferior alveolar nerve is extremely important for clinical practice, since, according to Milken et al. (2006) 
the procedure for anesthesia of the inferior alveolar nerve may cause damages to the peripheral nerves, and the accurate mechanism for it is unknown, as well as its prevention and treatment. Still according to the same authors, the conventional regional block techniques are associated with risks and complications, such as neurological and vascular disorders, intravascular injections and muscular disorders.

Studies approaching morphometry of the mandibular foramen in domestic felines with no defined breed (Barroso et al. 2009), mandibular foramen of crab-eating fox (Souza Junior et al. 2013) and the mandibular, mental and infraorbital foramens of maned wolf (Moraes 2016) have been previously conducted, however, there is still no data on the morphometry of the hoary fox mandibular foramen.

Therefore, the aim was describing morphometry of the hoary fox mandibular foramen, and associating its position with anatomic reference points in the mandible, thus providing support for more effective local anesthetic block of the inferior alveolar nerve in such species.

\section{MATERIALS AND METHODS}

Eight hemimandibles taken from four adult corpses (two males and two females) of Lycalopex vetulus (Lund, 1842), components of the research property of the Anatomy Laboratory of the Biological Science College of the Federal University of Goiás (UFG), Campus Catalão, were used. The mandibles were prepared by, firstly, removing the skin and soft tissues of the head region, with subsequent temporal mandibular disjointing. Then, the mandibles were subjected to chemical maceration with sodium hydroxide $\left(\mathrm{NaOH}\right.$, Lavitex $^{\circledR}$, concentration 98\%-99\%) during 30 minutes for cleaning, and later bleached through immersion into water solution of hydrogen peroxide $\left(\mathrm{H}_{2} \mathrm{O}_{2}\right.$, Dinâmica ${ }^{\circledR}$, concentration $\left.30 \%-36 \%\right)$, with 1:10 dilution, during 30 minutes.

For topographic record, the radiography of a hemimandible was taken, displaying the mandibular foramen and the mandibular canal position (Fig.1).

After this stage, the biometric information was taken in each hemimandible by a single analyzer and in duplicate, using the digital electronic caliper Starrett ${ }^{\circledR}$ (capacity $0-150 \mathrm{~mm}$, resolution $0.01 \mathrm{~mm}$, accuracy $\pm 0.02 \mathrm{~mm}$ ). Based on the studies conducted by Barroso et al. (2009), Souza Junior et al. (2013) and Moraes (2016), measurements were adapted and taken in each hemimandible as follows: $\mathrm{LAM}=$ distance from the side border of the condylar process to the root of the mandibular medial incisor; SAM = distance from the ventral and alveolar borders of the mandible, taken between the fourth mandibular premolar and the first mandibular molar; MFVB $=$ distance from the caudal edge of the mandibular foramen ventral border to the ventral border of the mandible in such level; MFANG $=$ distance from the caudal edge of the mandibular foramen ventral border to the dorsal edge of the angular process; MFCOND = distance from the caudal edge of the mandibular foramen ventral border to the medial end of the condylar process; MFCOR = distance from the caudal edge of the mandibular foramen ventral border to the dorsal edge of the caudal border of the coronoid process (Fig.2).

The morphometric data obtained was submitted to descriptive statistical analysis (arithmetic mean, standard deviation, and coefficient of variation) and to student t-test $(\mathrm{p}=0.05)$ with $95 \%$ confidence interval, using the software BioEstat ${ }^{\circledR} 5.3$. The anatomic nomenclature used to designate the identified structures was in accordance with the International Committee on Veterinary Gross Anatomical Nomenclature (I.C.V.G.A.N. 2017). The study was approved

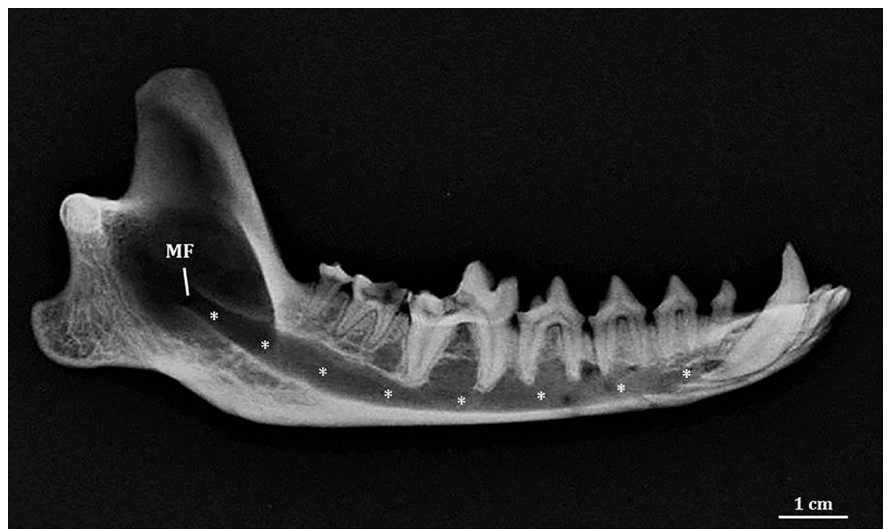

Fig.1. Lateromedial radiographic image of right hemimandible of an adult female of Lycalopex vetulus, highlighting the mandibular foramen (MF) and the mandibular canal (*).

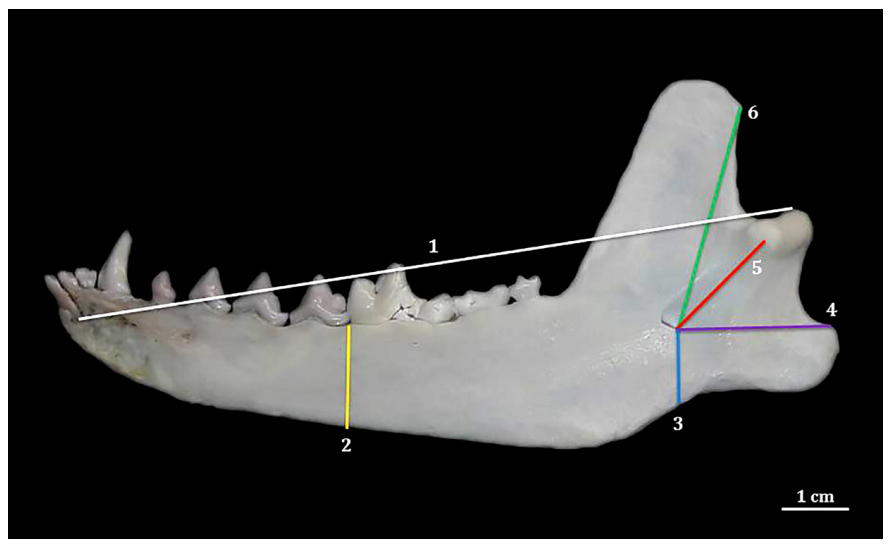

Fig.2. Medial face of right hemimandible of an adult female of Lycalopex vetulus, showing the LAM (1), SAM (2), MFVB (3), MFANG (4), MFCOND (5) and MFCOR (6) measurements.

by the Board of Ethics in Animal Use of the Federal University of Uberlândia, protocol no081/14, and the Board of Ethics in Animal Use of the University Center of Patos de Minas - Unipam, protocol no. $14 / 17$.

\section{RESULTS}

Each hemimandible was comprised of body, angle and ramus. The mandible body in side view showed in its rostral third three mental foramens, being one rostral, lower and ventral to the mandibular medial incisor, one caudal, with intermediate size and ventrally located to the third mandibular premolar, and one medium, upper and immediately ventral to the first mandibular premolar. Along the mandible body, in its alveolar border, were identified in each hemimandible I3/C1/PM4/M3. Laterally, the mandible angle was marked by a deep masseteric fossa dorsally extending to the mandible ramus. At the mandible angle ventral border, a marked angular incisure delimited the transition from the mandible body to the angle. Such incisure was caudally extended and ended in the angular process of the mandible. The dorsal projection of the mandible ramus was characterized by the presence of two processes, being the most caudal one named condylar 
process of the mandible, rostrally joined by a non-articular depression, dorsal mandibular incisure, to the mandible coronoid process. One ventral mandibular incisure was noticed between the angular and condylar processes of the mandible in a caudal border.

The hemimandibles were joined in the rostral third of the mandible body through a joint of the symphysis type, it being evident in a medial view. Yet in such view, at the level of the transition point between the mandible body and angle, near the coronoid process projection, the crevice to the mylohyoid nerve was evidenced branching in the caudodorsal rostral direction. The mandibular foramen was located in the mandible angle, ventrally to the insertion area of the temporal muscle and perpendicularly to the dorsal edge of the angular incisure, representing the caudal opening of the mandibular canal, which extended rostrally to the mental foramens. Caudoventrally to such foramen, at the median surface of the angular process, the fossa to the median pterygoid muscle was viewed (Fig.3A,B).

Table 1 and 2 show the arithmetic means and standard deviations related to each measure, the coefficients of variation and the values obtained in the t-test for comparison between the mean values of the hemimandibles of each antimere.

The mean biometry of the longitudinal axis of the hemimandibles was $99.67 \pm 1.14 \mathrm{~mm}$ (LAM), there being no statistically significant difference $(p=0.186)$ between the left $(100.15 \pm 1.43 \mathrm{~mm})$ and right $(99.19 \pm 0.73 \mathrm{~mm})$ antimeres. Measurements concerning the sagittal axis showed a mean value of $13.46 \pm 0.16 \mathrm{~mm}$ (SAM), and the left hemimandibles have a mean value of $13.37 \pm 0.18 \mathrm{~mm}$, and the right ones, $13.55 \pm 0.08 \mathrm{~mm}$, there being no difference between such antimeres $(\mathrm{p}=0.113)$.

The caudal edge of the mandibular foramen ventral border was, in average, $8.79 \pm 0.50 \mathrm{~mm}$ distant from the mandible ventral border (MFVB), there being no difference $(p=0.066)$ between the mean values of the left $(8.45 \pm 0.18 \mathrm{~mm})$ and right $(9.14 \pm 0.48 \mathrm{~mm})$ hemimandibles. Such point was still in a mean manner distant from the angular process dorsal edge by $17.69 \pm 1.07 \mathrm{~mm}$ (MFANG), there being no statistical

difference $(p=0.073)$ between the mean measures of the left $(16.82 \pm 0.71 \mathrm{~mm})$ and right $(18.56 \pm 0.28 \mathrm{~mm})$ antimeres.

The caudal edge of the mandibular foramen ventral border was distant from the condylar process medial end in average by $15.61 \pm 0.47 \mathrm{~mm}$ (MFCOND), there being no statistical relevance $(\mathrm{p}=0.097)$ between the median of the left $(15.89 \pm 0.22 \mathrm{~mm})$ and right (15.34 $\pm 0.54 \mathrm{~mm})$ antimeres. The mentioned point also did not have statistically significant variance $(p=0.062)$ between the median of the left $(29.66 \pm 0.22 \mathrm{~mm})$ and right $(30.27 \pm 0.49 \mathrm{~mm})$ antimeres, when conducting the measurements up to the dorsal edge of the coronoid process caudal border (MFCOR), being the mean value of such measurement $29.96 \pm 0.48 \mathrm{~mm}$.

Table 1. Values of the morphometric measurements of the left and right hemimandibles of a Lycalopex vetulus (arithmetic mean \pm standard deviation)

\begin{tabular}{lcc}
\hline Measurements & Left hemimandibles $(\mathrm{mm})$ & Right hemimandibles $(\mathrm{mm})$ \\
\hline LAM & $100.15 \pm 1.43$ & $99.19 \pm 0.73$ \\
SAM & $13.37 \pm 0.18$ & $13.55 \pm 0.08$ \\
MFVB & $8.45 \pm 0.18$ & $9.14 \pm 0.48$ \\
MFANG & $16.82 \pm 0.71$ & $18.56 \pm 0.28$ \\
MFCOND & $15.89 \pm 0.22$ & $15.34 \pm 0.54$ \\
MFCOR & $29.66 \pm 0.22$ & $30.27 \pm 0.49$
\end{tabular}

Table 2. Values of the morphometric measurements of the hemimandibles $(\mathrm{n}=8)$ of a Lycalopex vetulus

\begin{tabular}{lccc}
\hline Measurements & $\begin{array}{c}\text { Arithmetic mean and } \\
\text { Standard deviation } \\
(\mathrm{mm})\end{array}$ & $\begin{array}{c}\text { Coefficient of } \\
\text { variation (\%) }\end{array}$ & $p$-test \\
\hline LAM & $99.67 \pm 1.14$ & 1.15 & 0.186 \\
SAM & $13.46 \pm 0.16$ & 1.20 & 0.113 \\
MFVB & $8.79 \pm 0.50$ & 5.68 & 0.066 \\
MFANG & $17.69 \pm 1.07$ & 6.04 & 0.073 \\
MFCOND & $15.61 \pm 0.47$ & 3.04 & 0.097 \\
MFCOR & $29.96 \pm 0.48$ & 1.59 & 0.062
\end{tabular}

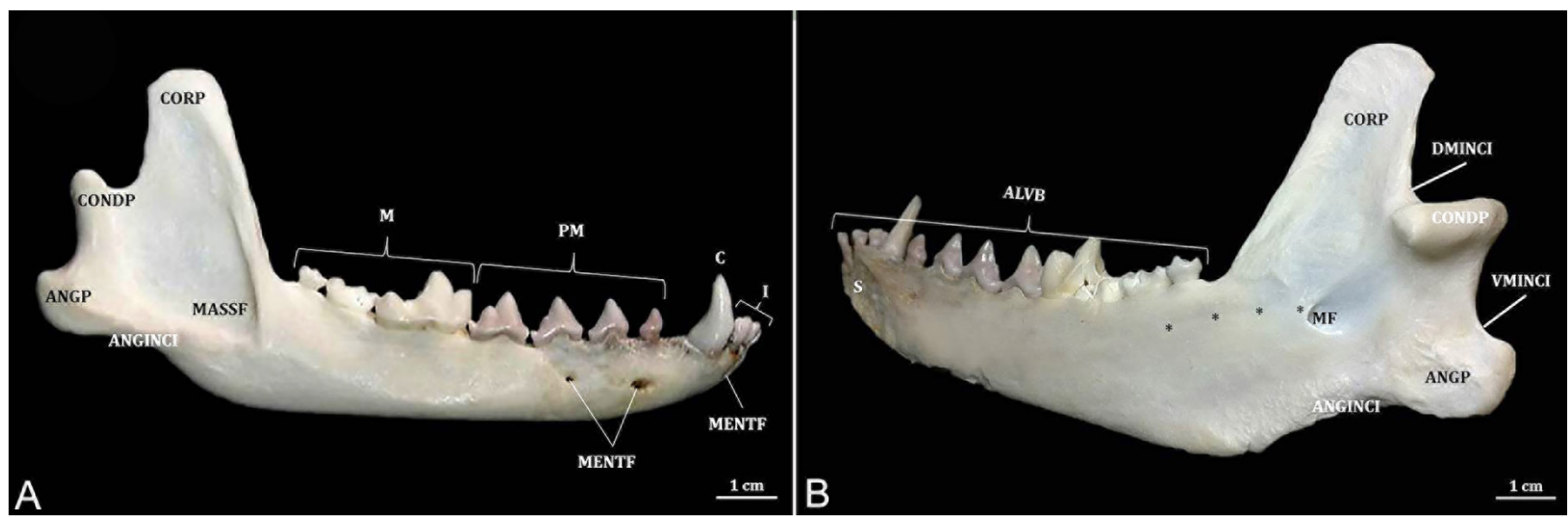

Fig.3. (A) Lateral and (B) mediocaudal faces of right hemimandible of an adult female of Lycalopex vetulus, evidencing the coronoid process (CORP), condylar process (CONDP), angular process (ANGP), masseteric fossa (MASSF), mental foramens (MENTF), angular incisure (ANGINCI), dorsal mandibular incisure (DMINCI), ventral mandibular incisure (VMINCI), mandibular foramen (MF), mandibular symphysis $(\mathrm{S})$, alveolar border (ALVB), crevice to the mylohyoid nerve $\left({ }^{*}\right)$, mandibular incisors (I), canine (C), premolars (PM) and molar (M). 


\section{DISCUSSION}

As to description of the left and right hemimandibles of a hoary fox, these may be divided into body, angle and ramus, as described by Sisson (1986) for carnivores.

Three mental foramens were viewed at the rostral end of the mandible body side face, corroborating in number with the studies disclosed by Evans \& DeLahunta (1994) for domestic dogs. Moraes (2016) in turn reports a great oscillation in the number and location of such foramens in the Chrysocyon brachyurus, and such variations were more frequent in relation to the caudal foramens. The inferior teeth of a Lycalopex vetulus by hemimandible (I3/C1/PM4/M3) was similar to the studies mentioned for other canidae, such as Canis lupus familiaris (Evans \& DeLahunta 1994), Atelocynus microtis, Cerdocyon thous, Chrysocyon brachyurus and Lycalopex gymnocercus (Cheida et al. 2011). Evans \& DeLahunta (1994) also mention that the incisors, canine, first premolars and the last molars, have only one root each. The last three premolars and the first two molars, in turn, have two roots each. Such morphology was also present in the hoary fox, and could be confirmed through radiographic examination, not being required to proceed to dental extraction for such certification.

Sisson (1986), Evans \& DeLahunta (1994) and König \& Liebich (2016) mention the presence of the masseteric fossa at the side surface of the mandible ramus, however, in the hoary fox, such bone accident began in the mandible angle, and it extends dorsally towards the mandible ramus. The mandible angle ventral border showed a non-articular depression named angular incisure. It extends caudally, delimiting the transition between body and angle, ending in the mandible angular process.

In the hoary fox, the mandibular foramen was located at the mandible angle medial face, while Sisson (1986) in carnivores, Souza Junior et al. (2013) in the crab-eating fox, and Moraes (2016) in the maned wolf, report the presence of this caudal opening in the medial face of the mandible ramus. Evans \& DeLahunta (1994), in turn, for domestic dogs, and König \& Liebich (2016) for domestic animals, report only the presence of such foramen in the mandible medial face. This study showed that the mandibular foramen was positioned ventrally to the insertion area of the temporal muscle, corroborating with the information described by Godinho \& Getty (1986) and Evans \& DeLahunta (1994) for carnivores and Souza Junior et al. (2013) for the crab-eating fox.

Such foramen was also located perpendicularly to the dorsal edge of the angular incisure in the L. vetulus, being similar to the studies stressed by Moraes (2016) for the maned wolf. However, it is different from the study of Souza Junior et al. (2013), which highlights a position relatively more rostral of the mandibular foramen in relation to such incisure for the crab-eating fox.

Still assessing the hoary fox mandible medial face, there was evidence of the crevice to the mylohyoid nerve, projected in the caudodorsal rostral direction, to the transition point between the mandible body and angle, near the initial coronoid process. Godinho \& Getty (1986) describe the mylohyoid nerve position for domestic carnivores, as being arranged ventrally and laterally to their paternal stem. In accordance with the above-mentioned authors, it is construed that such nerve is lodged over the crevice, thus, such characteristic may be assumed as a variant to projection of such bone accident for the L. vetulus.

König \& Liebich (2016) describe for domestic animals, the mandible ramus as the dorsal extension of the mandible body, it being comprised of the condylar process caudally, and by the coronoid process rostrally. Assessment of such mandible region of a $L$. vetulus enables to assume certain similarity to the studies of such authors, but in the concerned specimens, the mandible ramus extends from the angle region of it. Presence of two non-articular depressions between the mandible processes of a hoary fox allows for naming the separations between the angular and condylar processes from ventral mandibular incisure, and between the condylar and coronoid processes from dorsal mandibular incisure.

Among the main blocks used to provide appropriate analgesia of different regions of the oral cavity, there is the inferior alveolar block (Holmstrom et al. 2004), having a key procedure for efficient technique, determination of anatomic landmarks (Pachaly \& Gioso 2001, Pessutti et al. 2001), being vital to know the mandibular foramen location (Nicholson 1985). Such regional block is efficient in ipsilateral stunning of the mandibular teeth and soft tissues, being possible to be conducted using the intra-oral or extra-oral techniques in domestic dogs (Gross et al. 1997, Holmstrom et al. 2004, Hale 2007, Egger \& Love 2009). Indications for this anesthetic procedure include extractions of ipsilateral mandibular teeth, periodontal surgery, endodontic treatment, biopsies and mandibulectomy (Rochette 2005, Woodward 2008, Pascoe 2012).

LAM and SAM measurements were also conducted by Barroso et al. (2009), Souza Junior et al. (2013) and Moraes (2016), studying domestic felines with no defined breed, crab-eating fox and maned wolf respectively, and although not having direct relationship with the mandibular foramen position, it provides the idea of the longitudinal and sagittal measurements of the mandible. It should also be stressed that, for L. vetulus, statistically significant differences were not noticed in any of the measurements made, when comparing the left and right hemimandibles.

Regarding the anesthetic block of the inferior alveolar nerve to the level of its penetration into the mandibular foramen of maned wolf, Moraes (2016) indicates that the needle should be introduced perpendicularly and dorsally from the depression present in the mandible body caudal third, and near the lingual face of the bone by $11.40 \mathrm{~mm}$. Barroso et al. (2009) suggest for domestic cats with no defined breed, introduction of the needle between 4.10 and $4.40 \mathrm{~mm}$, from the mandible ventral border.

For domestic dogs, in turn, Gross et al. (1997) recommend dorsal penetration of the needle by 1 to $2 \mathrm{~cm}$ along the mandible median surface, from $0.50 \mathrm{~cm}$ rostral to the angular process. Higher values were published by Souza Junior et al. (2013) studying the crab-eating fox. Such authors recommend penetration of the needle by $12.10 \mathrm{~mm}$ for females, and $13.60 \mathrm{~mm}$ for males, perpendicularly to the ventral border of the mandible of such specimens.

For the hoary fox, it may be indicated that the needle should be introduced perpendicularly to the dorsal edge of the angular incisure in average $8.79 \mathrm{~mm}$, overlapped to the medial face of the mandible angle, and the technique mentioned herein corroborates with the recommendations 
by Beckman \& Legendre (2002), Holmstrom et al. (2004), Hale (2007) and Egger \& Love (2009), which indicate that the depression present in the ventral border of the mandible should be used as anatomic reference when introducing the needle for conducting the extra-oral technique of anesthetic block of the inferior alveolar nerve.

Egger \& Love (2009) also mention the angular process as a landmark for advancing the needle in the temporary stunning process of the inferior alveolar nerve in domestic dogs. Souza Junior et al. (2013) recommend that for this type of access in the $C$. thous, the needle should be introduced $20.40 \mathrm{~mm}$, and in diagonal from the angular process, however, such angle before the angular process was not stressed. In respect of the $C$. brachyurus, Moraes (2016) proposes penetrating the needle by $30 \mathrm{~mm}$ from the angular process, near the lingual face and angled at $20-25^{\circ}$ with the mandible body ventral border. Lower values were determined by Barroso et al. (2009) for Felis catus, requiring introduction of the needle about 12.37 and $12.57 \mathrm{~mm}$, also from the angular process. For the L. vetulus, the needle shall be introduced in average $17.69 \mathrm{~mm}$, perpendicularly, in contact with the mandible angle medial face, and in caudal-rostral projection from the dorsal edge of the angular process, for the anesthetic to be deposited nearer the inferior alveolar nerve.

The values provided for the hoary fox are lower than those reported by the above-mentioned authors by studying other wild canidae, such as crab-eating fox (Souza Junior et al. 2013) and maned wolf (Moraes 2016). However, such fact may have occurred due to such researchers take their measurements starting from the rostral border of the mandibular foramen, which is a reference not used in this study. The methodology adopted for the Lycalopex vetulus aims to preserve the neural structures of injuries possibly caused by penetrating the needle during the anesthetic procedure.

Silva et al. (2006) also indicated anesthetic application points for blocking the inferior alveolar nerve in cats. By dissecting the facial, retropharyngeal and lateral and medial mandibular sections of 10 male felines, the accurate point for the anesthetic procedure to be conducted was defined. Application of $1.0 \mathrm{ml}$ of Lidocaine $2 \%$ in each animal, with introduction of the needle by approximately $1.0 \mathrm{~cm}$, dorsally angled at $30^{\circ}$, medially or laterally to the palatoglossal arch, enabled the successful block in the five animals used $(100 \%)$, with no side effects and adverse reactions.

Milken et al. (2006) showed in a similar manner the efficiency of such form of local block, using $1.0 \mathrm{mg} / \mathrm{kg}$ of ropivacaine in 20 adult cats (100\%), with application site $1.0 \mathrm{~cm}$ rostral to the angular process and $0.5 \mathrm{~cm}$ dorsal to the ventral border of the right mandible ramus. The application site was determined by dissecting the mandibles of three Feline corpses. All studied animals showed anesthesia of the right lateral and ventral region of the mandibles.

Findings such as these show the wide range of possibilities for varying the relative position of the mandibular foramen, even among species from the same order, which justifies obtainment of accurate data for each species (Moraes 2016). Although such anesthetic procedures are considered frequent, easy to conduct and require using anatomic references to be conducted (Gross et al. 1997, Holmstrom et al. 2004, Hale 2007, Egger \& Love 2009), a lack of morphometric studies of the mandibular foramen in animals (Moraes 2016), especially wild ones, is noted.
According to Moraes (2016), the anesthetic procedures in wild species are required to be developed and enhanced, because most of such techniques were designed for domestic animals, with researches which would evidence procedures with support of the anatomy of each wild animal being indispensable. Thus, we can assume that extrapolation of the anatomic references used in domestic dogs may lead to greater index of failures in practice with wild canidae (Souza Junior et al. 2013).

The anesthetic technique of the inferior alveolar nerve is the most important regional block and used in the human dental care, and even so it has high failure percentage (15 to 20\%) (Rizzolo \& Madeira 2006, Strini et al. 2006). Among the several factors which infer a successful procedure, one may highlight the inaccuracy in locating the mandibular foramen (Strini et al. 2006, Lima et al. 2011), highly due to the variable location in individuals (Nicholson 1985, Blanton \& Roda 1995, Afsar et al. 1998, Potocnik \& Bajrovic 1999, Rizzolo \& Madeira 2006).

Lack of instruction in relation to the anatomy, associated with the technical deficiencies, hinder the obtainment of anesthesia and endanger other anatomic structures (Gregori \& Santos 1996). Block allows for analgesia for several hours after the procedure, minimizes the general anesthesia plan (Beckman \& Legendre 2002, Hale 2007), the inflammatory tissue reaction and central sensitivity to pain (Cediel et al. 1999). Such benefits are increasingly desirable in medicine of wild canidae due to the high rate of occurrence of dental and mandibular fractures, complex drug administration, as well as frequent weak condition of the patients upon the surgical procedure (Pachaly \& Gioso 2001, Pessutti et al. 2001). However, if these are incorrectly conducted, they may generate complications deriving from intramuscular injections (lockjaw, muscular pain or limited mouth movement) and anesthesia of the facial nerve (transitory facial paralysis) (Evers \& Haegerstam 1991).

\section{CONCLUSIONS}

Mandibles of Lycalopex vetulus had morphology similar to the previously described for other canidae species. Variations were noted in relation to the topographic description of the mandibular foramen, crevice to the mylohyoid nerve, mandible ramus, masseteric fossa, angular, dorsal mandibular and ventral mandibular incisures.

Enhanced anesthetic block of the inferior alveolar nerve of adult specimens of hoary fox may be indicated, by penetrating the needle perpendicularly to the dorsal edge of the angular incisure in average $8.79 \mathrm{~mm}$, overlapped to the medial face of the mandible angle. Alternatively, the access may also be made by introducing the needle in average $17.69 \mathrm{~mm}$ perpendicularly, in contact with the medial face of the mandible angle, and in caudal-rostral projection from the dorsal edge of the angular process.

Conflict of interest statement.- The authors declare that they have no conflict of interest.

\section{REFERENCES}

Afsar A., Haas D.A., Rossouw P.E. \& Wood R.E. 1998. Radiographic localization of mandibular anesthesia landmarks. Oral Surg., Oral Med., Oral Pathol., Oral Radiol. 86(2):234-241.<http://dx.doi.org/10.1016/S1079-2104(98)901317> <PMid:9720101> 
Barroso R.M.V., Ferreira F.A., Silva R.M. \& Lima E.M.M. 2009. Morphometric analysis of the mandibular foramen of cats (Felis catus Linnaeus, 1758) with no defined breed. Bioscience J. 25(4):135-142.

Beckman B. \& Legendre L. 2002. Regional nerve blocks for oral surgery in companion animals. Compend. Cont. Educ. Pract. Vet. 24(6):439-444.

Blanton P.L. \& Roda R.S. 1995. The anatomy of local anesthesia. J. California Dental Assoc. 23(4):55-69. <PMid:7643190>

Brasil 2002. Biodiversidade brasileira: avaliação e identificação de áreas e ações prioritárias para conservação, utilização sustentável e repartição dos benefícios da biodiversidade nos biomas brasileiros. Ministério Do Meio Ambiente, Secretaria de Biodiversidade e Florestas, Brasília, p.193-195.

Cediel R., Sánchez M., López-San Roman J., Tendillo F. \& Viloria A. 1999. Anestesia em odontologia, p.97-110. In: Acaso F.S.R., Orozco A.W. \& Muniz I.T. (Eds), Atlas de Odontologia de Pequenos Animais. Manole, São Paulo.

Cheida C.C., Nakano-Oliveira E., Fusco-Costa R., Rocha-Mendes F. \& Quadros J. 2011. Ordem Carnivora, p.235-288. In: Reis N.R., Peracchi A.L., Pedro W.A \& Lima I.P. (Eds), Mamíferos do Brasil. 2ª ed. Nelio R. dos Reis, Londrina.

Chiarello A.G., Aguiar L.M.S., Cerqueira R., Melo F.R., Rodrigues F.H.G. \& Silva V.M.F. 2008. Mamíferos ameaçados de extinção no Brasil, p.681-885. In: Machado A.B.M., Drummond G.M. \& Paglia A.P. (Eds), Livro Vermelho da Fauna Brasileira Ameaçada de Extinção. MMA, Fundação Biodiversitas, Brasília.

Costa C.H.N. \& Courtenay 0. 2003. A new record of the hoary fox Pseudalopex vetulus in north Brazil. Mammalia 67(4):593-594. <http://dx.doi. org/10.1515/mamm-2003-0416>

Dalponte J.C. 1997. Diet of hoary fox, Lycalopex vetulus, in Mato Grosso, Brazil. Mammalia 61(4):537-546.

Dalponte J.C. 2009. Lycalopex vetulus (Carnivora: Canidae). Mammalian Species 847(Spec.):1-7.

Dalponte J.C. \& Courtenay O. 2004. Hoary fox Pseudalopex vetulus (Lund, 1842), p.72-76. In: Sillero-Zubiri C., Hoffmann M. \& Macdonald D.W. (Eds), Canids: foxes, wolves, jackals and dogs. Status Survey and Conservation Action Plan, IUCN/SSC Canid Specialist Grou. Gland, Switzerland and Cambridge, UK

Egger C. \& Love L. 2009. Local and regional anesthesia techniques. Part 3. Blocking the maxillary and mandibular nerves. Vet. Med. 104(6):12-15.

Evans H.E. \& DeLahunta A. 1994. Miller, Guia para a Dissecação do Cão. 3a ed. Guanabara Koogan, Rio de Janeiro, p.156-159.

Evers H. \& Haegerstam H. 1991. Introdução à Anestesia Local Odontológica. Manole, São Paulo. 96p.

Ferreira-Silva E. \& Lima E.S. 2006. Termite predation by the hoary fox Pseudalopex vetulus (Lund) (Carnivora, Canidae), in a pasture in Mato Grosso, Central Brazil. Mammalia 70(3/4):255-260. <http://dx.doi org/10.1515/MAMM.2006.043>

Godinho H.P. \& Getty R. 1986. Sistema nervoso periférico, p.1583-1595. In: Getty R. (Eds), Sisson \& Grossman anatomia dos animais domésticos. 5a ed. Guanabara Koogan, Rio de Janeiro.

Gregori C. \& Santos W. 1996. Anestesias Intrabucais em Odontologia. Sarvier, São Paulo. 272p

Gross M.E., Pope E.R., Obrien D., Dodam J.R. \& Polkow-Haight J. 1997. Regional anesthesia of the infraorbital and inferior alveolar nerves during noninvasive tooth pulp stimulation in halothane-anesthetized dogs. J. Am. Vet. Med. Assoc. 211(11):1403-1405. <PMid:9394889>

Hale F. 2007. Local anesthesia in veterinary dentistry. CUSP 7:1-5.

Hellyer P.W. \& Gaynor J.S. 1998. Acute postsurgical pain in dogs and cats. Compend. Cont. Educ. Pract. Vet. 20:140-153.

Holmstrom S.E., Frost P.F. \& Eisner E.R. 2004. Veterinary Dental Techniques for the Small Animal Practitioner. 3rd ed. W.B. Saunders, Philadelphia.689p.
Hungerford L.L., Mitchell M.A., Nixon C.M., Esker T.E., Sullivan J.B., Koerkenmeier R. \& Marretta M. 1999. Periodontal and dental lesions in raccoons from a farming and a recreational area in Illinois. J. Wildl. Dis. 35(4):728-734. <http://dx.doi.org/10.7589/0090-3558-35.4.728><PMid:10574532>

I.C.V.G.A.N. 2017. Nomina Anatomica Veterinaria. 6th ed. International Committee on Veterinary Gross Anatomical Nomenclature, Editorial Committee, Hannover, Ghent, Columbia, Rio de Janeiro. 178p.

IUCN 2017. Red List of Threatened Species. Avaliable at <www.iucnredlist. org > Accessed on Feb. 15, 2017.

Jácomo A.T.A., Silveira L. \& Diniz-Filho J.A.F. 2004. Niche separation between the maned wolf (Chrysocyon brachyurus), the crab-eating fox (Dusicyon thous) and the hoary fox (Dusicyon vetulus) in central Brazil. J. Zoo. Wildl. Med. 262(1):99-106.

Juarez K.M. \& Marinho-Filho J. 2002. Diet, habitat use and home ranges of sympatric canids in central Brazil. J. Mamm. Evol. 83(4):925-933. <http:// dx.doi.org/10.1644/1545-1542(2002)083<0925:DHUAHR>2.0.C0;2>

König H.E. \& Liebich H.G. 2016. Anatomia dos Animais Domésticos: texto e atlas colorido. 6 ${ }^{\mathrm{a}}$ ed. Artmed, Porto Alegre, p.71-73.

Lemos F.G., Facure K.G. \& Azevedo F.C. 2011. Comparative ecology of the hoary fox and the crab-eating fox in a fragmented landscape in the Cerrado biome at central Brazil, p.143-160. In: Rosalino L.M. \& Gheler-Costa C. (Eds), Middle-Sized Carnivores in Agricultural landscapes. Nova Science Publishers Inc, New York

Lemos F.G., Azevedo F.C., Beisiegel B.M., Jorge R.P., Paula R.C., Rodrigues F.H.G. \& Rodrigues L.A. 2013. Avaliação do risco de extinção da Raposa-docampo Lycalopex vetulus (Lund, 1842) no Brasil. Biod. Bras. 3(1):160-171.

Lima D.S.C., Figuerêdo A.A., Rocha E.A., Costa V.H.M.V., Castro M.P., Silva R.C.P., Chagas G.L., Araújo L.P., Mendonça V.R.R., Gravina P.R. \& Meneses J.V.L. 2011. Estudo anatômico do forame mandibular e suas relações com pontos de referência do ramo da mandíbula. Revta Bras. Cirurg. Craniomaxilofacial 14(2):91-96.

Lumb W.V. \& Jones E.W. 2014. Anestesiologia e Analgesia Veterinária. 4⿳⺈ ed. Roca, São Paulo. 1192p.

Milken V.M.F., Freitas P.M.C., Eurides D., Silva F.O.C., Mota F.C.D., Naves E.A., Rezende R.J., Prieto L.A., Melo M.S. \& Goulart T.M.R. 2006. Bloqueio do nervo alveolar mandibular com ropivacaína a 0,5\% em gatos. Ciência Rural 36(2):550-554. <http://dx.doi.org/10.1590/S0103-84782006000200029>

Moraes F.M. 2016. Morfometria dos forames mandibular, mentual e infraorbital de lobo-guará Chrysocyon brachyurus, IIIiger, 1815 aplicada a bloqueio anestésicos. Doctoral Dissertation, Universidade Federal de Uberlândia, Uberlândia. 55p. Avaliable at < https://repositorio.ufu.br/ bitstream/123456789/17588/1/MorfometriaForamesMandibular.pdf> Accessed on 15 Jan. 2017

Nicholson M.L. 1985. A study of the position of the mandibular foramen in the adult human mandible. Anat. Rec. 212(1):110-112. <http://dx.doi. org/10.1002/ar.1092120116> <PMid:4073538>

Nickel R., Schummer A. \& Seiferle E. 1981. The Anatomy of the Domestic Animals. Verlag Paul Parey, Berlim. 141p.

Nowak R.M. 1999. Walker's Mammals of the World. 6th ed. The John Hopkins University Press, Baltimore.

Pachaly J.R. \& Gioso M.A. 2001. The oral cavity, p.457-463. In: Fowler M.E. \& Cubas Z.S. (Eds), Biology, Medicine and Surgery of South American Wild Animals. Iowa State University Press, Ames.

Pascoe P.J. 2012. Anesthesia and pain management, p.23-42. In: Verstraete F.J.M. \& Lommer M.J. (Eds), Oral and Maxillofacial Surgery in Dogs and Cats. Saunders Elsevier, Edinburgh. <http://dx.doi.org/10.1016/B9780-7020-4618-6.00004-X>.

Pessutti C., Santiago M.E.B. \& Oliveira L.T.F. 2001. Order Carnivora, p.279290. In: Fowler M.E. \& Cubas Z.S. (Eds), Family Canidae (dogs, foxes and maned wolves). Iowa State University Press, Ames. 
Potocnik I. \& Bajrovic F. 1999. Failure of inferior alveolar nerve block in endodontics. Dent. Traum. 15(6):247-251.<http://dx.doi.org/10.1111/j.1600-9657.1999. tb00782.x > <PMid:10825834>

Rizzolo R.J.C. \& Madeira M.C. 2006. Anatomia Facial com Fundamentos de Anatomia Sistêmica Geral. 2aㅡ ed. Sarvier, São Paulo. 343p.

Rochette J. 2005. Regional anesthesia and analgesia for oral and dental procedures. Vet. Clin. N. Am., Small Anim. Pract. 35(4):1041-1058, viii-ix. <http://dx.doi.org/10.1016/j.cvsm.2005.02.004> <PMid:15979524>

Silva M.L., Santana M.I., Araújo L.V. \& Elston F. 2006. Topografia e bloqueio anestésico do nervo mandibular em gatos. Revta Port. Ciênc. Vet. 101:187-192.

Sisson S. 1986. Osteologia do carnívoro, p.1337-1412. In: Getty R. (Ed.), Sisson/Grossman Anatomia dos Animais Domésticos. 5ae ed. Guanabara Koogan, Rio de Janeiro.

Souza Junior P., Pinto R.J.F., Freitas A.B. \& Carvalho N.C. 2013. Morfometria do forame mandibular de Cerdocyon thous (Linnaeus, 1766) (cachorrodo-mato). Biotemas 26(2):175-183.
Stimmelmayr R., Maier J.A.K., Persons K. \& Battig J. 2006. Incisor tooth breakage, enamel defects, and periodontitis in a declining Alaskan moose population. Alces 42:65-74.

Strini P.J.S.A., Júnior W.S., Rodrigues D.A., Strini P.J.S.A., Guimarães E.C. \& Júnior R.B. 2006. Avaliação topográfica do forame mandibular em peças anatômicas maceradas parcialmente dentadas e edêntulas. Revta Facul. Odont. Univ. Passo Fundo 11(2):111-115.

Trovati R.G., Campos C.B. \& Brito B.A. 2006. Nota sobre convergência e divergência alimentar de canídeos e felídeos (Mamalia: Carnivora) simpátricos no cerrado brasileiro. Neotrop. Biol. Conserv. 3(2):95-100.

Vieira C.C. 1946. Carnívoros do estado de São Paulo. Arq. Zool. 5(3):135-175.

Woodward T.M. 2008. Pain management and regional anesthesia for the dental patient. Topics Companion Anim. Med. 23(2):106-114. <http:// dx.doi.org/10.1053/j.tcam.2008.02.007><PMid:18482711>

Wozencraft W.C. 2005. Order Carnivora, p.532-628. In: Wilson D.E. \& Reeder D.M. (Eds), Mammal Species of the World: a taxonomic and geographic reference. 3rd ed. The Johns Hopkins University Press, Baltimore. 